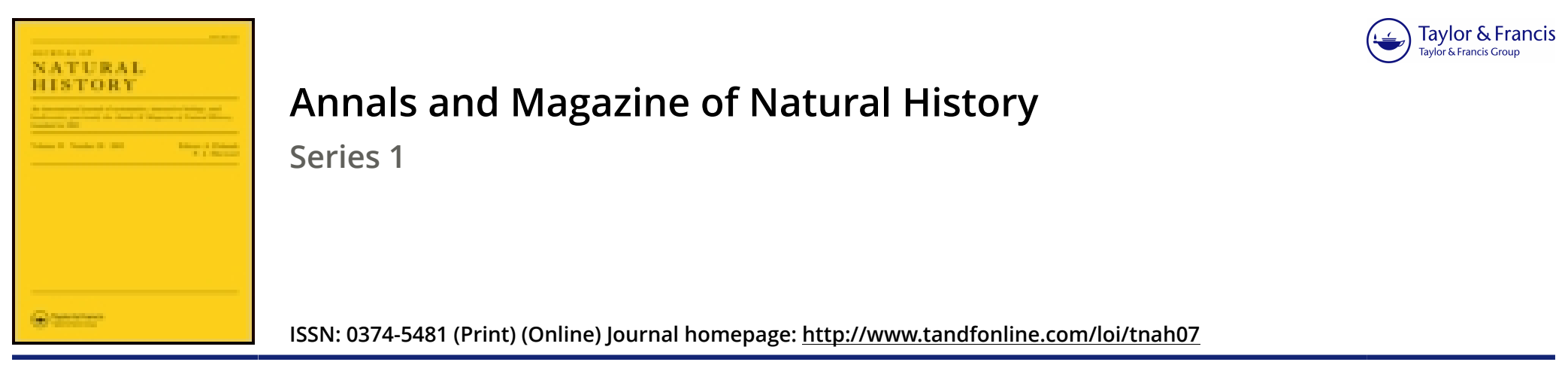

\title{
XIII.-A century of new genera and species of Orchidaceous plants
}

\section{Professor Lindley}

To cite this article: Professor Lindley (1845) XIII.-A century of new genera and species of Orchidaceous plants, Annals and Magazine of Natural History, 15:96, 106-108, DOI: 10.1080/037454809495263

To link to this article: http://dx.doi.org/10.1080/037454809495263

$$
\text { 册 Published online: } 17 \text { Dec } 2009 .
$$

Submit your article to this journal $\lceil\pi$

Q View related articles $₫$ 
This does not answer however for freshwater Algæ. Some of the specimens of marine Algæ, mounted in Goadby's solution, such as Codium tomentosum, Helminthocladia vermicularis, \&c., are admirable.

This method of preparing Algæ certainly requires some little expenditure of care and patience, but it will be found so satisfactory in its results as amply to compensate any additional pains; and when once the requisite arrangements have been made, the trouble in the case of individual specimens from time to time will not be found so great as might be expected.

It may be remarked that the method is equally applicable to other microscopical objects, and especially to those of vegetable physiology.

I am, my dear Sir, faithfully yours,

M. J. BERKELEY.

XIII.-A Century of new Genera and Species of Orchidaceous Plants. Characterized by Professor Lindley.

[Continued from vol. xii. p. 398.]

\section{Decade 3.}

21. Pheurothaldis Hartwegii ; caule medio laxe et longe vaginato, folio oblongo sessili amplexicauli, spatha obtusa carinata coriacea, spicis plurimis erectis rigidis secundifloris folio subrqualibus, sepalis disjunctis falcatis intus pubescentibus, labello cordato ovato obtuso basi auriculato (v. trilobo lobis lateralibus brevibus rotundatis) juxta sinus bilamellato.

Popayan (Hartweg).

Very like $P$. macrophylla. Stem a foot and more high. Leaf a span long. Spikes eighteen to twenty.

22. Pheurothaturs lavigata; caule angulato medio laxe et longe vaginato, folio oblongo sessili amplexicauli vernice quasi induere, spatha acuta carinata coriacea lævigata, spicis plurimis erectis ri' gidis secundifloris folio brevioribus, floribus omnino P. Hartwegii sed duplo majoribus.

Popayan (Hartweg).

Very like $P$. Hartwegii, but the leaves are more polished, the spikes often shorter, and especially the flowers are twice as large. Perhaps it is a mere variety.

23. STELIS maxima; folio oblongo obtuso, spica recta basi spathacea triplo longiore, bracteis amplexicaulibus cuspidatis internodiis brevioribus, floribus ventricosis disepalis, sepalis multistriatis concavis, ......

At the foot of Mount Tunguragua, at the height of 11,000 feet (Hartweg). 
A beautiful species, with flowers almost half an inch long, and apparently purple. It would be a Pleurothallis if its petals were not truncated and dwarf.

24. Stelis brevilabris; caulescens, folio lineari-lanceolato mucronato, spicis quadruplo longioribus solitariis erectis secundis strictis, bracteis cuspidatis internodiis brevioribus, sepalis lateralibus acutis supremo oblongo brevioribus.

Popayan (Hartweg).

Related to St. ascendens and lamellata, but easily distinguished by the drooping, ringent, almost 2-lipped flowers. Can it be St. elongata, H. B. K. ? but the description does not agree.

25. Pleurothallis convoluta; folio coriaceo convoluto, spicis pluribus folio brevioribus erectis, floribus lævibus, sepalis marginatis lateralibus ultra medium connatis, petalis duplo brevioribus obtusis diaphanis, labello longiore complicato apice spathulato acuto infra medium utrinque dilatato rotundato.

Popayan (Hartweg).

26. Plevrothaldis galeata; caule medio longe et laxe vaginato, folio petiolato cordato-oblongo obtuso, spatha subcoriacea obtusa, spicis filiformibus plurimis nutantibus folio brevioribus, sepalis lateralibus semiconnatis angustis erectis dorsali antico galeato membranaceo, petalis linearibus sepalis paulo brevioribus, labello cucullato rhombeo angulis rotundatis utrinque bilamellato apice crasso calloso.

Popayan (Hartweg).

Near Pl. macrophylla.

27. Pachyphrluum squarrosum; foliis recurvis squarrosis, labello obsolete trilobo callo a marginibus longe distante.

Popayan (Hartweg).

Much like $P$. distichum, except in the leaves and the form and callosity of the labellum.

28. Dialissa, gen. nov. Steli proximum. Calyx tubulosus, bilabiatus, antice ventricosus; labio altero bifido revoluto. Petala nana. Labellum indivisum, rectum. Columna nana, recta, biauris. Pollinia 2.

Dialissa pulchella. Spithamæa et ultri, cæspitosa. Caules teretes, monophylli, vaginis tubulosis membranaceis glabris vestiti. Folium petiolatum, lanceolatum, striatum, acutissimum, tridentatum; racemo striato, basi distanter vaginato triplo brevius. Bracteæ $\frac{\mathrm{I}}{2}$ pollicares, falcatæ, acutissimæ, perfoliatæ, canaliculatæ, glabræ, distichæ, floribus glabris æquales. Sepalum supremum subcordatum, erectum. Petala rhombea. Lahellum spathulatum, rotundatum, linea transversa elevata.

Popayan (Hartweg).

29. Gastropodium violaceum. Ramosum, distiche foliosum, foliis carnosis linearibus obtusis mucronulatis, vaginis striatis transverse 


\section{Mr. A. White on a new species of Longicorn Beetle.}

rugosis. Racemi breves, sessiles, terminales, cernui. Flores parvi, membranacei, violacei. Bracteæ subulatæ, membranaceæ. Sepala conniventia, ovata, libera. Petala lanceolata duplo minora. Labellum c. columna connatum, ventricosum, ovatum, callo tripartito ad basin. Columna brevis pyramidalis, partis liberæ marginibus latis crassis truncatis. Clinandrium nudum. Anthera plana, membranacea, 4-locularis. Pollinia 4, oblonga, collateralia, omnino sejuncta, filis totidem rectis, nec replicatis, lævibus, apice connatis colligata. Ovarium cuniculatum, antice ventricosum.

Popayan (Hartweg).

This genus is near the true species of Diothonea, and like it in habits. It differs in its naked anther-bed and in the structure of the pollen masses.

30. Restrepia cucullata; foliis oblongo-linearibus coriaceis acutis pedunculis filiformibus erectis brevioribus, sepalis lateralibus in unum lineari-lanceolatum connatis supremo angustissimo, petalis duplo brevioribus linearibus acuminatis, labello carnoso oblongo lævi tricarinato, columna cucullata.

Popayan (Hartweg).

XIV.-Description of an apparently new species of Longicorn Beetle from Mexico in the collection of the British Museum. By Adam Write, Assistant Zool. Dep. Brit. Mus.

[With a Plate.]

Is M. Delessert's 'Souvenirs d'un Voyage à l'Inde,' a very interesting account has been given by M. Perrotet, his companion, of the habits of the Dorysthenes montanus of Guérin, with which I shall commence this paper, more especially as the insect about to be described would be arranged close to it by many authors (such as Laporte de Castelnau), although at present we have no means of ascertaining whether the Prionacalus of this memoir, and Psalidognathus of Mr. G. R. Gray, like the East Indian genus alluded to, and unlike the majority of the group to which they belong, live on the ground in elevated places destitute of large trees. The D. montanus begins to appear above the surface of the ground about the end of April, and comes up in immense numbers till the beginning of the rainy season, which lasts from the end of May or during June. They appear in such swarms that the highways and by-paths are covered with them in some places, and it is said that the bears of the country, at the season when they abound, get up to the mountains to feed on them. They have been observed by MM. Delessert and Perrotet coming out of their holes in the ground, especially in the neighbourhood of Coonoor, Kotirgherris and other places amongst the Neelghories, where they may be seen white, yellow and brown, aceordingly as: 